\title{
Lack of Pleiotropic Compensation in Extracellular Protein Production by Hypoproducing Variants of Staphylococcus simulans biovar staphylolyticus
}

\author{
By JOHN M. ROBINSON, H. E. HEATH AND GARY L. SLOAN* \\ Department of Microbiology, The University of Alabama, Tuscaloosa, AL 35487, USA
}

(Received 25 July 1986)

\begin{abstract}
The changes in bacterial density, total extracellular protein and activities of three extracellular enzymes were monitored during growth of wild-type Staphylococcus simulans biovar staphylolyticus, a representative pleiotropic variant that produced decreased levels of the three extracellular enzymes, and a variant that produced only 5 of the 14 extracellular proteins secreted by the wild-type organism. Both variants produced less total extracellular protein than did the parental organism. SDS-PAGE of the proteins secreted by these hypoproducing variants showed that all of the extracellular proteins were produced in decreased amounts. No pleiotropic compensation in extracellular protein production was observed for these hypoproducing variants of $S$. simulans biovar staphylolyticus.
\end{abstract}

\section{INTRODUCTION}

Staphylococcus simulans biovar staphylolyticus [S. staphylolyticus (Sloan et al., 1982)] coordinately produces three extracellular enzymes: a staphylolytic endopeptidase, a micrococcolytic hexosaminidase and a thiol protease (Larrimore et al., 1982; Robinson et al., 1982). Moreover, most mutations affecting the production of any one of these enzymes similarly affect production of the other two as well (Larrimore et al., 1982; Rose et al., 1985).

Björklind \& Arvidson (1980) have reported the isolation of mutants of Staphylococcus aureus strain V8 with pleiotropic changes in extracellular protein production. They observed a decrease in the production of proteinases I and III, $\alpha$-toxin, staphylokinase, DNAase and acid phosphatase but an increase in the production of staphylocoagulase and protein A. More recently, Recsei et al. (1986) have described a derivative of $S$. aureus strain RN4282 that produced decreased amounts of toxic shock syndrome toxin, staphylokinase and three haemolysins but an increased amount of protein A. Likewise, Coleman (1981) has shown that a low $\alpha$-toxin-producing variant of $S$. aureus (Wood 46) also produced four other extracellular proteins at reduced levels; however, the differential rates of total extracellular protein formation by the hypoproducing variant and the parental strain were identical. As noted by Coleman (1981), this suggests that other extracellular proteins are produced at higher levels by this variant in order to compensate for decreased production of the five proteins, thereby keeping the extracellular protein-producing capacity saturated. Coleman termed this phenomenon pleiotropic compensation.

To test if pleiotropic compensation occurs in S. simulans biovar staphylolyticus, we determined the activities of three specific exoenzymes and the concentration of total extracellular protein produced by the wild-type organism, hypoproducers of the three enzymes and a variant that had lost all but 5 of the 14 extracellular proteins produced by the wild-type organism. In addition, the extracellular proteins were separated by SDS-PAGE to determine if there were variations in the levels of production of extracellular proteins other than the endopeptidase, hexosaminidase and protease.

\section{METHODS}

Bacterial strains. Staphylococcus simulans biovar staphylolyticus (NRRL B-2628) was originally obtained from W. C. Haynes (Northern Regional Research Center, Peoria, Ill, USA). Hypoproducing variants for 
endopeptidase, hexosaminidase and protease (e.g. strain LP1) were isolated by the procedure described by Larrimore et al. (1982). Strain NPR2 is a revertant of a pleiotropic nonproducer of the three exoenzymes; it was identified as endopeptidase-positive and subsequently was shown also to have regained hexosaminidase and protease.

Enzyme assays. Assays for the endopeptidase (Robinson et al., 1979) and for the hexosaminidase and protease (Robinson et al., 1980) have been described previously.

Growth conditions. Cultures were grown in a modification of lysostaphin production medium (Robinson et al., 1980). The modified medium contained (per litre): $60 \mathrm{~g}$ enzymic digest of casein ( $\mathrm{N}-\mathrm{Z}$ Amine E, Humko Sheffield Chemical), $5 \mathrm{~g} \mathrm{NaCl}$ and $2.5 \mathrm{~g} \mathrm{~K}_{2} \mathrm{HPO}_{4}$. For each organism, ten $500 \mathrm{ml}$ Erlenmeyer flasks containing $100 \mathrm{ml}$ of medium were inoculated with $5 \mathrm{ml}$ of an $18 \mathrm{~h}$ culture grown in the same medium and were incubated at $37^{\circ} \mathrm{C}$ with shaking at 250 r.p.m. Samples $(5 \mathrm{ml})$ were taken at $2 \mathrm{~h}$ intervals from 6 to $24 \mathrm{~h}$ and the cells were harvested by centrifugation at $12000 \mathrm{~g}$ for $10 \mathrm{~min}$ at $4{ }^{\circ} \mathrm{C}$. Bacterial density was determined by the procedure of Stormonth \& Coleman (1972). Extracellular protein was determined according to the procedure of Bradford (1976).

SDS-PAGE. Samples of supernatants were concentrated 10 -fold by ultrafiltration using Millipore immersible CX-10 ultrafiltration units. SDS-PAGE and protein staining were performed according to the procedure of Weber \& Osborn (1969) with gels made up to a concentration of $9 \%(w / v)$ acrylamide. Samples were loaded onto the gels based on equivalent dry cell weights of the cultures in order to compare the relative amount of each extracellular protein produced per cell. The gels were scanned at $565 \mathrm{~nm}$ with a Varian Cary 210 spectrophotometer.

\section{RESULTS AND DISCUSSION}

The relationship between growth of wild-type $S$. simulans biovar staphylolyticus and secretion of endopeptidase, hexosaminidase, protease and total extracellular protein is shown in Fig. $1(a)$. $S$. simulans biovar staphylolyticus and other staphylococci studied to date characteristically exhibit a biphasic pattern of extracellular protein formation, with increased production in the post-exponential phase of growth (Abbas-Ali \& Coleman, 1977; Coleman \& Abbas-Ali, 1977; Coleman et al., 1978; Robinson et al., 1980). In modified lysostaphin production medium, $S$. simulans biovar staphylolyticus had a $2 \cdot 6$-fold increase in the differential rate of extracellular protein production during post-exponential growth (Fig. 2). A scan of an SDS-polyacrylamide gel of concentrated extracellular proteins from the wild-type organism showed that the organism secreted at least 14 extracellular proteins ranging in molecular mass from 108 to $12.5 \mathrm{kDa}$ (Fig. $3 a$ ). The proteins of $38.5,25.9$ and $17.9 \mathrm{kDa}$ correspond to the hexosaminidase, endopeptidase and protease, respectively (H. Mody \& G. L. Sloan, unpublished data).

Strain LP1 was typical of several hypoproducing variants that have been studied in this laboratory. These strains were identified on the basis of hypoproduction of the endopeptidase as previously described (Larrimore et al., 1982) and subsequently were found also to be hypoproducers of hexosaminidase and protease. The relationship between growth of strain LP1 and secretion of the three exoenzymes and total extracellular protein is shown in Fig. $1(b)$. Growth of strain LP1 was quite similar to that of the wild-type organism; however, the levels of production of the three exoenzymes and extracellular protein were significantly less. Strain LP1 also had a biphasic pattern of extracellular protein production (Fig. 2). Whereas the differential rates of extracellular protein production for both the parental organism and strain LPI were quite similar during exponential growth, the hypoproducer exhibited only a $2 \cdot 0$-fold increase in the differential rate of extracellular protein formation during the post-exponential phase of growth. Therefore strain LPI was concluded to be deficient in its capacity for post-exponential extracellular protein production. Furthermore, a scan of an SDS-polyacrylamide gel of concentrated extracellular proteins from strain LP1 (Fig. $3 b$ ) showed that this variant produced less of each extracellular protein than did the wild-type organism. In fact, the $108 \mathrm{kDa}$ and $102 \mathrm{kDa}$ proteins produced by the parental organism could not be detected among the concentrated extracellular proteins from this hypoproducing organism.

Strain NPR2 is a revertant of a pleiotropic nonproducer of the endopeptidase, hexosaminidase and protease. The pleiotropic nonproducer was isolated as previously described (Larrimore et al., 1982). Strain NPR2 was isolated as an endopeptidase-positive revertant and subsequently was found also to have regained the ability to produce hexosaminidase and protease. The relationship between growth of strain NPR2 and secretion of the three exoenzymes and extracellular protein is shown in Fig. 1(c). Extracellular protein production by 


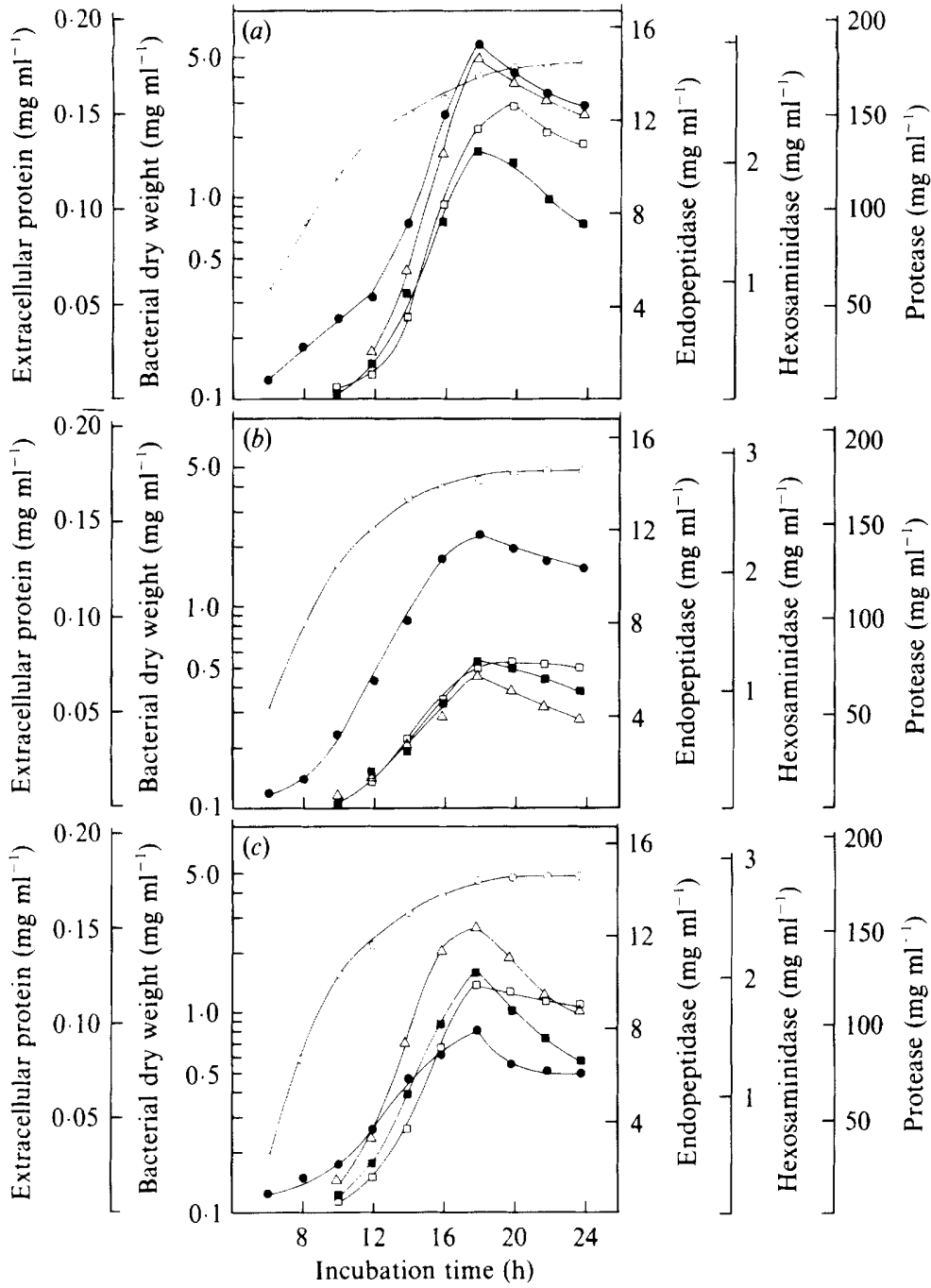

Fig. 1. Relationship between growth and secretion of endopeptidase, hexosaminidase, protease and total extracellular protein. The results shown are representative data from a single experiment; similar results were obtained upon repetition. (a) Wild-type $S$. simulans biovar staphylolyticus; (b) strain LPl, a hypoproducer for the three enzymes; $(c)$ strain NPR2, a revertant of a pleiotropic nonproducer of the three enzymes. $\bigcirc$, Bacterial dry weight; $O$, extracellular protein; $\square$, endopeptidase; hexosaminidase; $\triangle$, protease.

this organism also was biphasic (Fig. 2) but with only a $1 \cdot 8$-fold increase in the differential rate of extracellular protein production at the end of the exponential phase of growth. Therefore strain NPR2 was similar to other hypoproducing strains in that it was deficient in its capacity for postexponential extracellular protein production. In this case, only 5 of the 14 extracellular proteins produced by the wild-type organism could be detected by SDS-PAGE of the concentrated extracellular proteins from strain NPR2 (Fig. $3 c$ ). The underlying reason as to why this variant regained the ability to produce only 5 of 14 extracellular proteins is currently under investigation.

In this study we did not observe any pleiotropic compensation in extracellular protein production by hypoproducing variants of $S$. simulans biovar staphylolyticus as has been reported for S. aureus (Wood 46). Hypoproducing variants for the three extracellular enzymes also were 


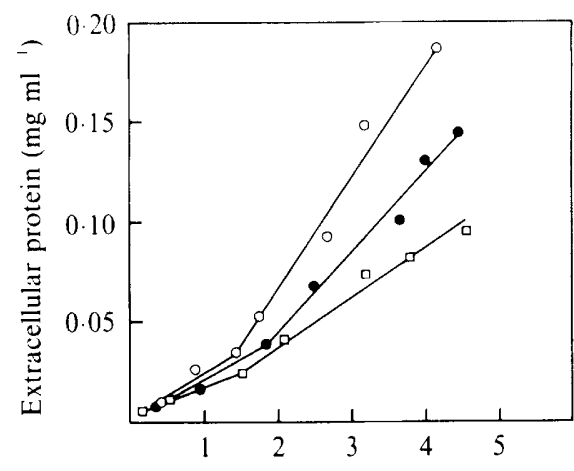

Bacterial dry weight $\left(\mathrm{mg} \mathrm{ml}^{-1}\right)$

Fig. 2. Relationship between extracellular protein secretion and growth. The data shown are from the experiment depicted in Fig. 1. O, Wild-type $S$. simulans biovar staphylolyticus; 0 , hypoproducing strain LP1; $\square$, revertant NPR2.
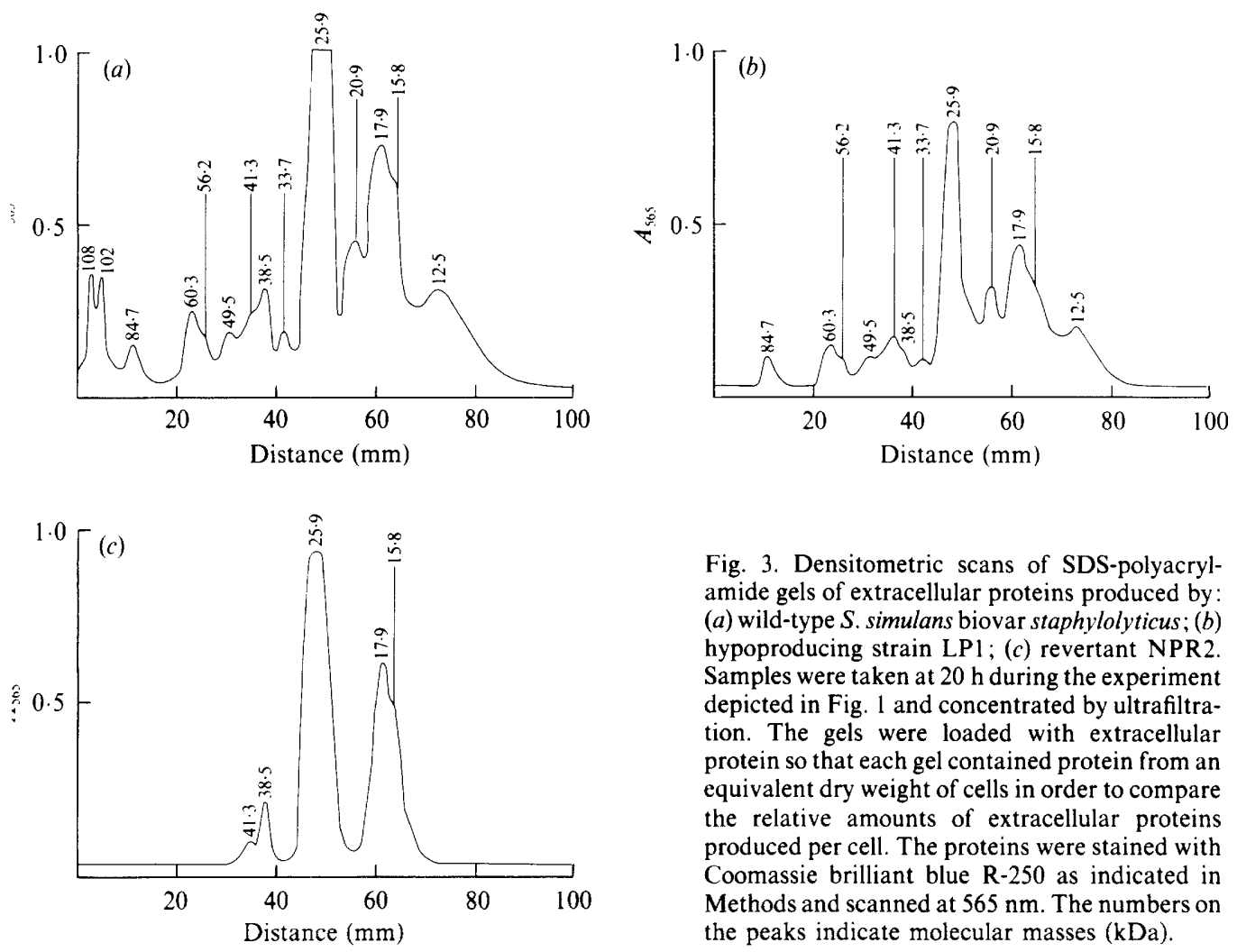

Fig. 3. Densitometric scans of SDS-polyacrylamide gels of extracellular proteins produced by: (a) wild-type $S$. simulans biovar staphylolyticus; (b) hypoproducing strain LP1; (c) revertant NPR2. Samples were taken at $20 \mathrm{~h}$ during the experiment depicted in Fig. 1 and concentrated by ultrafiltration. The gels were loaded with extracellular protein so that each gel contained protein from an equivalent dry weight of cells in order to compare the relative amounts of extracellular proteins produced per cell. The proteins were stained with Coomassie brilliant blue R-250 as indicated in Methods and scanned at $565 \mathrm{~nm}$. The numbers on the peaks indicate molecular masses $(\mathrm{kDa})$.

hypoproducers for all other extracellular proteins secreted by the organism. Furthermore, strain NPR2, which produced detectable levels of only 5 of the 14 extracellular proteins, also produced less total extracellular protein than did the wild-type organism. Engels \& Kamps (1982) similarly have shown for two strains of $S$. aureus that staphylocoagulase-negative mutants, which also lost $\alpha$-haemolysin and PV-leucocidin activity, produced considerably less total extracellular protein than did the wild-type organisms.

Our results and those of Engels \& Kamps (1982) indicate that mutations in staphylococci can 
cause an overall decrease in the capacity for extracellular protein production. On the other hand, the staphylococcal mutant characterized by Coleman (1981) exhibited decreased production of some extracellular proteins but increased production of others. These results are not necessarily contradictory. The mutants we and Engels \& Kamps (1982) have isolated could be deficient in a component required for synthesis or secretion of all extracellular proteins. Such mutants would not be expected to exhibit pleiotropic compensation. However, the mutant isolated by Coleman (1981) could be affected in its ability to synthesize specific subgroups of extracellular proteins. This type of mutant would be expected to show pleiotropic compensation if, for example, availability of ribosomes were the limiting factor for extracellular protein production. Isolation and characterization of additional mutants from $S$. simulans biovar staphylolyticus may yet yield variants that show pleiotropic compensation. In any event, the mutants described in this study seem to be specifically defective in protein secretion during the post-exponential phase of growth. Further characterization of such mutants may help to define components involved in extracellular protein production during secondary metabolism.

This research was supported in part by grants no. 1312 (to G.L.S.) and no. 1303 (to H.E.H.) from The University of Alabama Research Grants Committee.

\section{REFERENCES}

Abbas-Ali, B. \& Coleman, G. (1977). The characteristics of extracellular protein secretion by Staphylococcus aureus (Wood 46) and their relationship to the regulation of $\alpha$-toxin formation. Journal of General Microbiology 99, 277-282.

BJöRKLIND, A. \& ARVIDSON, S. (1980). Mutants of Staphylococcus aureus affected in the regulation of exoprotein synthesis. FEMS Microbiology Letters 7, 203-206.

BRADFORD, M. M. (1976). A rapid and sensitive method for the quantitation of microgram quantities of protein utilizing the principle of protein-dye binding. Analytical Biochemistry 72, 248-254.

Coleman, G. (1981). Pleiotropic compensation in the regulation of extracellular protein formation by a low $\alpha$-toxin producing variant of Straphylococcus aureus (Wood 46). Journal of General Microbiology 122, 1115.

Coleman, G. \& Abbas-Ali, B. (1977). Comparison of the patterns of increase in $\alpha$-toxin and total extracellular protein by Staphylococcus aureus (Wood 46) grown in media supporting widely differing growth characteristics. Infection and Immunity 17, 278-281.

Coleman, G., Jakeman, C. M. \& Martin, N. (1978). Patterns of total extracellular protein secretion by a number of clinically isolated strains of Staphylococcus aureus. Journal of General Microbiology 107, 189192.

ENGELS, W. \& KAMPS, M. A. F. (1982). The nature of the competitive ability of spontaneous staphylocoagulase-negative mutants of Staphylococcus aureus with respect to growth of the parent strains in continuous culture. Antonie van Leeuwenhoek 48, 6783.

Larrimore, S. A., Clark, S. B., Robinson, J. M., Heath, H. E. \& Sloan, G. L. (1982). Coordinate production of three exoenzymes by Staphylococcus staphylolyticus. Journal of General Microbiology 128, 1529-1535.

ReCSEI, P., KreISWIRTH, B., O'Reilly, M.,
Schlievert, P., Gruss, A. \& Novick, R. P. (1986). Regulation of exoprotein gene expression in Staphylococcus aureus by agr. Molecular and General Genetics 202, 58-61.

Robinson, J. M., Hardman, J. K. \& Sloan, G. L. (1979). Relationship between lysostaphin endopeptidase production and cell wall composition in Staphylococcus staphylolyticus. Journal of Bacteriology 137, 1158-1164.

Robinson, J. M., Keating, M. S. \& Sloan, G. L. (1980). The characteristics of extracellular protein secretion by Staphylococcus staphylolyticus. Journal of General Microbiology 118, 529-533.

Robinson, J. M., Larrimore, S. A., Craft, D. W., HeATH, H. E. \& SloAN, G. L. (1982). Effects of amino acids and derivatives of cyclic adenosine $3^{\prime}, 5^{\prime}$ monophosphate on the production of three exoenzymes by Staphylococcus simulans biovar staphylolyticus. Biochemical and Biophysical Research Communications 109, 730-737.

Rose, K. E., Heath, H. E. \& Sloan, G. L. (1985). Simple screening method for identification of nonpleiotropic mutants for exoenzyme production. Applied and Environmental Microbiology 49, 13351337.

Sloan, G. L., Robinson, J. M. \& Kloos, W. E. (1982). Identification of 'Staphylococcus staphylolyticus' NRRL B-2628 as a biovar of Staphylococcus simulans. International Journal of Systematic Bacteriology 32, 170-174.

Stormonth, D. A. \& Coleman, G. (1972). A rapid and convenient method for determining the dry weight of bacteria which show a tendency to form large aggregates. Journal of General Microbiology 71, 407408.

WEBER, K. \& OsBorN, M. (1969). The reliability of molecular weight determinations by dodecyl-sulfate polyacrylamide gel electrophoresis. Journal of Biological Chemistry 244, 4406-4412. 